\title{
PENDEKATAN CONTEXTUAL TEACHING AND LEARNING (CTL) DAN APLIKASINYA DALAM PEMBELAJARAN IPA SEKOLAH DASAR
}

\author{
Neng Mumun Kurniawan, Tati Sumiati \\ PGSD Kampus UPI di Purwakarta
}

\begin{abstract}
Abstrak: Penulisan karya ilmiah ini dilatarbelakangi oleh banyaknya siswa yang belum memahami konsep materi dan jawaban yang kurang tepat dalam menyelesaikan soal yang diberikan oleh guru. Selain itu ditemukan siswa yang meskipun mendapat nilai yang tinggi tetapi tidak mampu menerapkan apa yang diperoleh dalam kehidupan sehari-hari. Peran siswa lebih banyak hanya menerima informasi dari guru yang kemudian dihapalkan untuk ujian dan mendapatkan nilai. Hal tersebut diakibatkan karena kurang aktifnya siswa dalam proses pembelajaran, dimana metode atau pendekatan pembelajaran yang digunakan masih berpusat pada guru. Oleh karena itu diperlukan suatu cara belajar yang dapat meningkatkan pemahaman konsep siswa dalam pembelajaran IPA. Salah satu pendekatan tersebut adalah pendekatan Contextual Teaching and Learning. Pendekatan Contextual Teaching and Learning merupakan suatu pendekatan yang mengaitkan materi pembelajaran dengan kehidupan nyata sehingga membuat pembelajaran lebih bermakna dan mendorong siswa menerapkan pengetahuan yang dimilikinya dalam kehidupan sehari-hari. Dalam proses pembelajaran kontekstual melibatkan tujuh komponen utama pembelajaran efektif, yakni: kontruktivisme (contructivism), menemukan (inquiry), bertanya (questioning), masyarakat belajar (learning community), pemodelan (modeling), refleksi dan penelitian sebenarnya (authentic assessment). Dengan menerapkan pendekatan CTL dalam pembelajaran IPA, diharapkan hasil pembelajaran lebih bermakna bagi siswa. Proses pembelajaran berlangsung lebih alamiah dalam bentuk kegiatan siswa bekerja dan mengalami, bukan sekedar transfer pengetahuan dari guru kepada siswa.
\end{abstract}

Kata kunci : Pendekatan Contextual Teaching And Learning (CTL), Pembelajaran IPA, Sekolah Dasar

\section{PENDAHULUAN}

IImu Pengetahuan Alam atau yang disingkat dengan IPA adalah salah satu mata pelajaran pokok yang harus diajarkan di sekolah dasar. Hal ini dijelaskan oleh Samatowa (2011, hlm.4) bahwa alasan itu dapat digolongkan dalam empat golongan yakni:

a) bahwa IPA berfaedah bagi suatu bangsa; b) IPA merupakan mata pelajaran yang memberikan kesempatan berfikir kritis; c) bila IPA diajarkan melalui percobaanpercobaan yang dilakukan sendiri oleh anak, maka IPA bukan merupakan mata pelajaran yang bersifat hafalan belaka; d) IPA mempunyai nilai-nilai pendidikan yaitu mempunyai potensi yang dapat membentuk kepribadian anak secara keseluruhan.
Sejalan dengan pendapat tersebut, Jimmy (2014) mengungkapkan bahwa pembelajaran IPA di sekolah dasar harus meliputi 4 aspek, yaitu:

1) Sikap, yaitu pembelajaran IPA harus dapat menimbulkan dan mengembangkan rasa ingin tahu murid tentang benda/objek, fenomena alam, makhluk hidup, serta hubungan sebab akibat yang menimbulkan masalah baru yang dapat dipecahkan melalui prosedur yang benar, dan pembelajaran IPA harus selalu bersifat open ended yang memungkinkan siswa untuk mengembangkan pola pikirnya sesuai dengan minat dan kemampuan masing-masing; 2) proses, yaitu prosedur pemecahan masalah melalui metode ilmiah. Metode ilmiah meliputi penyusunan hipotesis, perancangan eksperimen atau percobaan, evaluasi, 
pengukuran, dan penarikan kesimpulan; 3) produk, yaitu berupa fakta, prinsip, teori, dan hukum; 4) aplikasi, yaitu penerapan metode ilmiah dan konsep IPA dalam kehidupan sehari-hari.

Salah satu upaya yang dapat dilakukan untuk meningkatkan kualitas pembelajaran IPA adalah melalui penerapan pendekatan kontekstual (Contextual Teaching and Learning). Kasmad dan Pratomo (2012, hlm.20) mengungkapkan bahwa

Kemampuan guru yang harus dimiliki pada saat proses pembelajaran di kelas yaitu membuat program rencana pembelajaran, penguasaan materi, menggunakan strategi atau model-model belajar, penerapan media yang relevan dengan tujuan dan mampu menerapkan atau melaksanakan evaluasi. Dari kemampuan guru tersebut salah satunya yang paling dominan penerapan strategi atau model-model pembelajaran yang mampu memberikan kesempatan kepada peserta didik untuk mengembangkan penguasaan materi, kompetensi pribadi, dan kemampuan memecahkan masalah dalam kehidupan sehari-hari. Salah satu pendekatan yang mampu mengembangkan kemampuan tersebut adalah Pendekatan Contextual Teaching and Learning.

Dalam pembelajaran yang menggunakan pendekatan kontekstual siswa memperoleh pengetahuan dengan mengalami sendiri apa yang dipelajarinya. Untuk itu, dalam pembahasan ini penulis akan memaparkan tentang pendekatan kontekstual dan aplikasinya dalam pembelajaran IPA di sekolah dasar.

\section{PENDEKATAN CONTEXTUAL}

\section{TEACHING AND LEARNING (CTL)}

Heriawan, dkk (2012, hlm.20) mengungkapkan bahwa "...CTL merupakan suatu konsep belajar dimana guru menghadirkan situasi dunia nyata ke dalam kelas dan mendorong siswa membuat hubungan antara pengetahuan yang dimilikinya dengan penerapannya dalam kehidupan mereka sebagai anggota keluarga dan masyarakat." Dengan konsep ini, hasil pembelajaran diharapkan lebih bermakna bagi siswa. Proses pembelajaran berlangsung lebih alamiah dalam bentuk kegiatan siswa bekerja dan mengalami, bukan sekedar transfer pengetahuan dari guru kepada siswa.

Takari (2009, hlm.38) mengungkapkan bahwa

pembelajaran kontekstual (CTL) yaitu konsep pembelajaran yang membantu guru mengaitkan antara materi yang diajarkan dengan situasi dunia nyata siswa dan mendorong siswa membuat hubungan antara pengetahuan yang dimilikinya dengan penerapannya dalam kehidupan mereka sehari-hari, dengan melibatkan 7 komponen utama pembelajaran efektif, yakni kontruktivisme (contructivism), bertanya (questioning), menemukan (inquiry), masyarakat belajar (learning community), pemodelan (modelling), dan penilaian sebenarnya (authentic assesment).

Asep , dkk (2007, hlm.156) mengungkapkan

pendekatan kontekstual sebagai suatu pendekatan pembelajaran yang memfasilitasi kegiatan belajar siswa untuk mencari, mengolah, dan menemukan pengalaman belajar yang lebih bersifat kongkrit (terkait dengan kehidupan nyata) melalui pelibatan aktivitas belajar mencoba melakukan dan mengalami sendiri (learning by doing). Dengan demikian pembelajaran tidak sekedar dilihat dari sisi produk, akan tetapi yang terpenting adalah proses. Oleh karena itu tugas guru adalah mensiasati strategi pembelajaran bagaimana yang dipandang lebih efektif dalam membimbing kegiatan belajar siswa agar dapat menemukan apa yang menjadi harapannya. Dalam proses pembelajaran kontekstual melibatkan tujuh komponen utama pembelajaran efektif, yakni: kontruktivisme (contructivism), menemukan (inquiry), bertanya (questioning), masyarakat 
belajar (learning community), pemodelan (modeling), refleksi dan penelitian sebenarnya (authentic assessment).

Dari pengertian di atas dapat disimpulkan bahwa pendekatan Contextual Teaching and Learning merupakan suatu pendekatan yang mengaitkan materi pembelajaran dengan kehidupan nyata sehingga membuat pembelajaran lebih bermakna dan mendorong siswa menerapkan pengetahuan yang dimilikinya dalam kehidupan sehari-hari.

\section{Karakteristik Pendekatan Contextual} Teaching and Learning

Syaefudin (2009, hlm.129) terdapat lima karakteristik penting dalam proses pembelajaran yang menggunakan pendekatan CTL diantaranya :

a) Pembelajaran dengan model CTL merupakan proses pengaktifan pengetahuan yang sudah ada. Artinya apa yang akan dipelajari tidak terlepas dari pengetahuan yang sudah dipelajari, dengan demikian pengetahuan yang akan diperoleh siswa adalah pengetahuan yang utuh yang memiliki keterkaitan satu sama lain.

b) Pembelajaran yang kontekstual adalah belajar dalam rangka memperoleh dan menambah pengetahuan baru, yang diperoleh dengan cara deduktif, atinya pembelajaran dimulai dengan cara mempelajari secara keseluruhan kemudian memperhatikan detailnya.

c) Pemahaman pengetahuan artinya pengetahuan yang diperoleh bukan untuk dihafal tetapi untuk dipahami dan diyakini. Misalnya dengan cara meminta tanggapan dari yang lain tetntang pengetahuan yang diperolehnya dan berdasarkan tanggapan tersebut baru pengetahuan itu dikembangkan.

d) Mempraktekkan pengetahuan dan pengalaman tersebut, artinya pengetahuan dan pengalaman yang diperolehnya harus diaplikasikan dalam kehidupan siswa, sehingga tampak perubahan perilaku siswa. e) Melakukan refleksi terhadap strategi pengembangan pengetahuan. Hal ini dilakukan sebagai umpan balik untuk proses perbaikan dan penyempurnaan strategi.

Komponen - komponen Pendekatan Contextual Teaching and Learning

Heriawan, dkk (2012, hlm.24) pembelajaran kontekstual ini memiliki tujuh komponen yang harus dikembangkan yaitu :

1. Konstruktivisme (Contructivisme)

Kontruktivisme merupakan landasan berpikir (filosofi) dalam pendekatan CTL, yaitu bahwa pengetahuan dibangun oleh manusia sedikit demi sedikit yang hasilnya diperluas melalui konteks yang terbatas. Pengetahuan bukanlah seperangkat fakta-fakta, konsep atau kaidah yang siap untuk diambil dan diingat.

2. Menemukan (inquiry)

Menemukan merupakan kegiatan inti dari pendekatan CTL, melalui upaya menemukan akan memberikan penegasan bahwa pengetahuan dan keterampilan serta kemampuankemampuan lain yang diperlukan bukan merupakan hasil dari mengingat seperangkat fakta-fakta, tetapi merupakan hasil menemukan sendiri. Stahapan-tahapan inkuiri adalah: (a) observasi; (b) bertanya; (c) mengajukan dugaan; (d) pengumpulan data; (e) penyimpulan.

3. Bertanya (Questioning)

Unsur lain yang menjadi karakteristik utama CTL adalah kemampuan dan kebiasaan untuk bertanya. Pengetahuan yang dimiliki seseoarang selalu bermula dari bertanya. Oleh karena itu bertanya merupakan strategi utama dalam pendekatan CTL. Kegiatan bertanya berguna untuk : (a) menggali informasi, baik administrasi maupun akademik; (b) mengecek pemahaman siswa; (c) membangkitkan respon siswa; (d) mengetahui sejauh mana keingin tahuan siswa; (e) mengetahui hal-hal yang diketahui siswa; (f) memfokuskan perhatian siswa; (g) membangkitkan lebih banyak lagi pertanyaan dari siswa; 
(h) menyegarkan kembali pengetahuan yang telah dimiliki siswa.

\section{Masyarakat Belajar (Learning Community)}

Maksud dari masyarakat belajar adalah membiasakan siswa untuk melakukan kerjasama dan memanfaatkan sumber belajar dari teman-teman belajarnya. Seperti yang disarankan dalam learning community, bahwa hasil pembelajaran diperoleh dari kerjasama dengan orang lain melalui berbagai pengalaman (sharing). Melalui sharing ini anak dibiasakan untuk saling memberi dan menerima, sifat ketergantungan yang positif dalam learning community dikembangkan.

5. Pemodelan ( modeling)

Dalam sebuah pembelajaran keterampilan atau pengetahuan terstentu, ada model yang bisa ditiru. Model itu memberi peluang yang sangat besar bagi guru untuk memberi contoh cara mengerjakan sesuatu, dengan begitu guru memberi model tentang bagaimana belajar. Model dapat dirancang dengan melibatkan siswa, seorang siswa dapat ditunjuk untuk memberikan contoh. Siswa contoh tersebut dikatakan sebagai model, siswa lain dapat menggunakan model tersebut sebagai standar kompetensi yang harus dicapai.

\section{Refleksi (Reflection)}

Refleksi adalah cara berpikir tentang apa yang baru dipelajari atau berpikir ke belakang tentang apa-apa yang sudah dilakukan dimasa yang lalu, siswa mengendapkan apa yang baru dipelajarinya sebagai struktur pengetahuan baru yang merupakan pengayaan atau revisi dari pengetahuan sebelumnya. Pada saat refleksi, siswa diberi kesempatan untuk mencerna, menimbang, membandingkan, menghayati, dan melakukan diskusi dengan dirinya sendiri (learning to be).

7. Penilaian sebenarnya (Authentic Assessment)

Authentic Assessment adalah proses pengumpulan berbagai data yang bisa memberikan gambaran belajar siswa. Gambaran perkembangan belajar siswa perlu diketahui oleh guru agar bisa memastikan bahwa siswa mengalami proses pembelajaran yang benar. Kemajuan belajar dinilai dari proses, bukan melalui hasil, dan dengan berbagi cara. Tes hanyalah salah satunya, itulah hakikat penilaian yang sebenarnya. Penilaian tidak hanya dilakukan oleh guru, tetapi bisa juga teman atau orang lain. karakteristik penilaian sebenarnya adalah: (a) dilaksanakan selama dan sesudah proses pembelajaran berlangsung; (b) bisa digunakan dalam formatif maupun sumatif; (c) yang diukur keterampilan dan performansi, bukan hanya mengingat fakta;

berkesinambungan; (e) terintegrasi; (f) dapat digunakan sebagai feed back.

Dengan demikian pembelajaran yang benar memang seharusnya ditekankan pada upaya membantu siswa agar mampu mempelajari sesuatu, bukan ditekankan pada diperolehnya sebanyak mungkin informasi di akhir periode pembelajaran.

\section{APLIKASI CTL DALAM PEMBELAJARAN IPA SEKOLAH DASAR}

De Vito (dalam Samatowa, 2010, hlm.104) mengungkapkan bahwa '...pembelajaran IPA yang baik harus mengaitkan IPA dengan kehidupan sehari-hari siswa. Siswa diberi kesempatan untuk mengajukan pertanyaan, membangkitkan ide-ide siswa, membangun rasa ingin tahu tentang sesuatu yang ada di lingkungannya.' Menurut Darmodjo (dalam Samatowa, 2011, hlm.2) 'Ilmu Pengetahuan Alam adalah yang rasional dan objektif tentang alam semesta dengan segala isinya.' Sejalan dengan pendapat Winaputra (dalam Samatowa, 2011, hlm.3) 'Ilmu Pengetahuan Alam adalah ilmu yang berhubungan dengan gejala alam dan kebendaan yang sistematis yang tersusun secara teratur.'

Pembelajaran IPA di sekolah dasar hendaknya membuka kesempatan kepada siswa untuk memupuk rasa ingin tahu, sehingga siswa dapat mengembangkan kemampuan bertanya dan mencari jawaban berdasarkan bukti, 
bersikap aktif dan mengembangkan cara berfikir ilmiah.

\section{Penerapan Pendekatan Contextual Teaching and Learnig di Kelas \\ Wisudawati dan Sulistyowati (2015,} hlm.50) mengemukakan bahwa pengembangan setiap asas-asas atau komponen-komponen CTL dalam pembelajaran, dapat dilakukan melalui langkah-langkah pembelajaran CTL sebagai berikut:

a. Mengembangkan pemikiran siswa untuk melakukan kegiatan belajar lebih bermakna, apakah dengan cara bekerja sendiri, menemukan sendiri, dan mengkonstruksikan sendiri pengetahuan dan keterampilan baru yang harus dimilikinya.

b. Melaksanakan sejauh mungkin kegiatan inkuiri untuk semua topik yang diajarkan

c. Mengembangkan sifat ingin tahu siswa melalui memunculkan pertanyaan-pertanyaan

d. Menciptakan masyarakat belajar, seperti melalui kegiatan kelompok, berdiskusi, dll.

e. Menghadirkan model sebagai contoh pembelajaran, bisa melalui ilustrasi, model, bahkan yang sebenarnya.

f. Membiasakan anak untuk melakukan refleksi dari setiap kegiatan pembelajaran yang telah dilakukan.

g. Melakukan assessmen yang sebenarnya dengan berbagai cara

\section{Contoh Penerapan Pendekatan CTL dalam Pembelajaran IPA Sekolah Dasar}

Materi yang akan diterapkan berdasarkan Kurikulum Tingkat Satuan Pendidikan (KTSP) 2006 adalah sifatsifat cahaya kelas $V$ SD dengan Standar Kompetensi (SK): Menerapkan sifat-sifat cahaya melalui kegiatan membuat suatu karya/model dan Kompetensi Dasar (KD): Mendeskripsikan sifat-sifat cahaya.

\section{Rencana Pelaksanaan Pembelajaran} (RPP)

Nama Sekolah : SDN Cicinde
Utara I

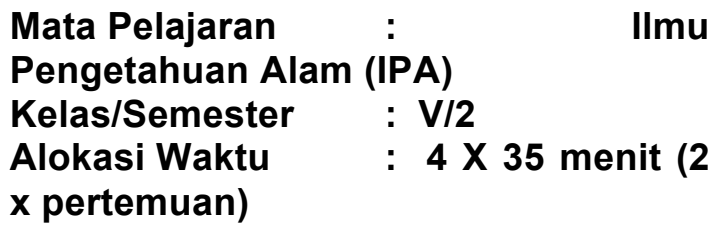

A. Standar Kompetensi

6. Menerapkan sifat-sifat cahaya melalui kegiatan membuat suatu karya/model

B. Kompetensi Dasar

6.1 Mendeskripsikan sifat-sifat cahaya

C. Indikator Pembelajaran

1. Menjelaskan pengertian sifat cahaya merambat lurus dan menembus benda bening

2. Mengklasifikasikan benda yang dapat tembus cahaya dan tidak tembus cahaya

3. Memberikan 3 contoh benda tembus cahaya dan tidak tembus cahaya

4. Menyimpulkan kegunaan sifat-sifat cahaya dalam kehidupan sehari-hari

5. Menafsirkan sifat cahaya merambat lurus dan menembus benda bening

6. Memprediksi sifat cahaya merambat lurus dan menembus benda bening

7. Membandingkan sifat cahaya merambat lurus dan menembus benda bening

D. Tujuan Pembelajaran

1. Melalui tanya jawab, siswa dapat menjelaskan pengertian sifat cahaya merambat lurus dan menembus benda bening dengan benar

2. Melalui percobaan, siswa dapat mengklasifikasikan benda yang dapat tembus cahaya dan tidak tembus cahaya dengan benar

3. Melalui percobaan, siswa dapat memberikan 3 contoh benda tembus cahaya dan tidak tembus cahaya dengan benar

4. Melalui diskusi, siswa dapat menyimpulkan kegunaan sifat-sifat cahaya dalam kehidupan sehari-hari dengan benar

5. Melalui tanya jawab, siswa dapat menafsirkan sifat cahaya merambat lurus dan menembus benda bening dengan benar

6. Melalui diskusi, siswa dapat memprediksi sifat cahaya merambat 
lurus dan menembus benda bening dengan benar

7. Melalui tanya jawab, siswa dapat membandingkan sifat cahaya merambat lurus dan menembus benda bening dengan benar

\section{E. Materi Pokok}

\section{Cahaya dan Sifatnya}

Sifat-sifat cahaya (merambat lurus dan menembus benda bening) dan kegunaannya dalam kehidupan sehari-hari

\section{F. Pendekatan, dan Metode Pembelajaran \\ Pendekatan Contextual \\ Teaching and Learning (CTL) Metode : tanya jawab, percobaan, dan diskusi}

G. Langkah-langkah pembelajaran

1. Kegiatan Pendahuluan (15 menit)

- Mengkondisikan siswa dalam situasi pembelajaran yang kondusif

- Berdoa dan absensi

- Menyampaikan tujuan pembelajaran

- Menggali pengetahuan awal siswa melalui pertanyaan (apersepsi) Guru : "pada pagi hari apakah matahari sudah menyinari rumah mu?"

Siswa

Guru : "terlihat darimana cahaya matahari yang menyinari rumah mu?"

Siswa

Guru : "lalu pernahkah kalian mengamati arah rambatan cahaya yang masuk melalui celah-celah jendela rumah mu?"

Siswa : ". ".

Guru : "bagaimana jika kaca jendela tersebut ditutup dengan triplek atau kertas karton? Apakah cahaya matahari dapat masuk?" Siswa : "..........."

\section{(kontruktivisme dan bertanya)}

2. Kegiatan Inti (40 menit)

- Guru menjelaskan sifat cahaya dapat merambat lurus dan menembus benda bening
- Guru menunjuk salah seorang siswa untuk membuktikan bahwa cahaya menembus benda bening (Pemodelan)

- Guru membagi siswa ke dalam kelompok

- Guru menunjuk perwakilan kelompok untuk mengambil alat-alat yang digunakan untuk percobaan

- Guru membagikan LKS tentang langkah-langkah percobaan

- Siswa secara berkelompok melakukan percobaan tentang sifatsifat cahaya (Inkuiri)

- Setelah melakukan percobaan, siswa berdiskusi tentang benda yang dapat tembus cahaya dan tidak tembus cahaya (Masyarakat Belajar)

- Siswa melaporkan hasil diskusi dengan menunjuk salah satu perwakilan dari kelompok

3. Kegiatan Akhir (15 menit)

- Siswa dan guru bertanya jawab untuk mengingat kembali kegiatan yang telah dilakukan (Bertanya dan Refleksi)

- Guru memberikan evaluasi tertulis mengenai pembelajaran yang telah dilakukan (Penilaian yang sebenarnya)

- Guru menutup pembelajaran dengan berdo'a bersama-sama

\section{H. Sumber dan Alat / Bahan} Pembelajaran

Sumber : Buku Sains untuk Sekolah Dasar Kelas 5. Penulis: Haryanto. Penerbit: Erlangga

Alat / bahan : Percobaan 1 (cahaya dapat merambat lurus)

1. Lilin

2. Korek api

3. 3 buah sterofoam berukuran $15 \mathrm{~cm} x$ $15 \mathrm{~cm}$ yang telah dilubangi

4. Double tip

Percobaan 2 (cahaya menembus benda bening)

1. Lampu senter 
2. Gelas bening

3. Gelas berisi air kopi

4. Batu

5. Sterofoam

6. Potongan triplek

7. Plastik bening

I. Penilaian

1. Penilaian proses

- Jenis penilaian : Non tes

- Bentuk Penilain : Observasi

- Instrumen Penilaian: Lembar Observasi

2. Penilai Hasil

- Jenis penilaian : Tes

- Bentuk Penilain : Pilihan Ganda

- Instrumen Penilaian: Butir soal, kunci jawaban dan kriteria penilaian

\section{KESIMPULAN}

Pendekatan kontekstual (CTL) dapat meningkatkan kualitas pembelajaran IPA sekolah dasar. Pada pendekatan kontekstual (CTL), siswa mengalami langsung materi atau konsep yang diajarkan dan mendorong siswa menerapkan pengetahuan yang dimilikinya dalam kehidupan sehari-hari. Proses pembelajaran berlangsung lebih alamiah dalam bentuk kegiatan siswa bekerja dan mengalami, bukan sekedar transfer pengetahuan dari guru kepada siswa. Kelas bukanlah tempat untuk mencatat atau menerima informasi dari guru, akan tetapi kelas digunakan untuk saling membelajarkan.

\section{DAFTAR RUJUKAN}

Asep, dkk. 2007. Belajar dan Pembelajaran Sekolah Dasar. Bandung : UPI Press.

Heriawan, A, dkk. 2012. Metodologi Pembelajaran Kajian Teoritis Praktis. Banten: LP3G

Jimmy. 2014. Pendekatan Pembelajaran IPA. [online] tersedia : https://jimmyadolfratupa.wordpres s.com/2014/03/20/pendekatanpembelajaran-ipa-di-sd/. Diakses 12 Februari 2016

Kasmad, M dan Pratomo, S. 2012. Model-Model

Pembelajaran
Berbasis Paikem. Tangerang: PT. Pustaka Mandiri

Samatowa, Usman. 2011. Pembelajaran IPA di Sekolah Dasar. Jakarta: PT Indeks.

Syaefudin Sa'ud, Udin. 2009. Inovasi Pendidikan. Bandung : UPI Press.

Takari, Enjah. 2009. Pembelajaran IPA dengan SAVI dan Kontekstual. Sumedang: PT Genesindo

Wisudawati, A.W dan Sulistyowati, E. 2015. Metodologi Pembelajaran IPA. Jakarta: Bumi Antariksa

\section{RIWAYAT HIDUP}

Neng Mumun Kurniawan adalah mahasiswa Universitas Pendidikan Indonesia kampus Purwakarta semester 8 yang sedang menyelesaikan skripsi pada jenjang S1 PGSD. Lahir di Karawang, 16 April 1994. Berlatar belakang pendidikan di SD Negeri Cicinde Utara II lulus pada tahun 2006, kemudian melanjutkan sekolahnya di SMP Negeri 1 Banyusari lulus pada tahun 2009. Pada tahun itu pula melanjutkan sekolahnya di SMA Negeri 1 Cikampek lulus tahun 2012. Kemudian melanjutkan studinya pada program S1 Pendidikan Guru Sekolah Dasar Universitas Pendidikan Indonesia Kampus Purwakarta. Pembaca bisa menghubungi penulis melalui e-mail: neng.mumun@student.upi.edu

Tati Sumiati adalah Dosen Universitas Pendidikan Indonesia kampus Purwakarta. Lahir di Purwakarta, 13 November 1956. Menyelesaikan studi DIII di IKIP Bandung jurusan Fondasifondasi Pendidikan lulus tahun 1980. Mendapat gelar Dra dari IKIP Bandung jurusan Filsafat dan Sosiologi Pendidikan pada tahun 1989. Menyelesaikan S1 di IKIP Padang jurusan Pendidikan IPA SD tahun 1995. Kemudian melanjutkan S2 di Universitas Pendidikan Indonesia jurusan Pendidikan Umum (PU) lulus pada tahun 2005. Pembaca bisa menghubungi penulis melalui e-mail: sumiatitati5@gmail.com 